Proc. Estonian Acad. Sci. Biol. Ecol., 2003, 52, 2, 149-165

\title{
Macrozoobenthos assemblages in highly productive areas of the Estonian coastal sea
}

\author{
Ilmar Kotta ${ }^{\mathrm{a}, \mathrm{b}}$, Helen Orav-Kotta ${ }^{\mathrm{a}, \mathrm{c}}$, and Jonne Kotta ${ }^{\mathrm{a}^{*}}$ \\ ${ }^{\text {a }}$ Estonian Marine Institute, University of Tartu, Marja 4D, 10617 Tallinn, Estonia \\ ${ }^{\mathrm{b}}$ Tallinn Pedagogical University, Narva mnt. 25,10120 Tallinn, Estonia \\ ${ }^{c}$ Institute of Zoology and Hydrobiology, University of Tartu, Vanemuise 46, 51014 Tartu, Estonia
}

Received 15 April 2002, in revised form 13 February 2003

\begin{abstract}
Bank slopes, fronts between different basins, river estuaries, and sites in the vicinity of municipal wastewater discharges are the most productive areas of the Estonian coastal sea. In these areas macrozoobenthos biomass exceeded significantly the values of the adjacent sea. The concentration of total nitrogen correlated positively with the benthic biomass. An increase in the species number of macrozoobenthos followed the decrease of nutrients in Pärnu Bay whereas the relationship was insignificant in other regions. When the water currents were slow a clear negative effect of the discharged effluents on the benthic communities was observed. Very high nutrient loads result in the accumulation of hydrogen sulphide in the sediment and the disappearance of benthos in these areas.
\end{abstract}

Key words: macrozoobenthos, nutrients, river estuaries, sewage discharge, upwelling.

\section{INTRODUCTION}

Highly productive sea areas are often important with respect to marine living resources and, hence, increasing attention has been paid to a variety of processes related to these localities (e.g. Le Fèvre, 1986; Levinton, 1995). High productivity is supported by elevated nutrient influxes originating either from deep sea, i.e. upwelling areas, coupled with internal nutrient loads (Kahru et al., 1984; Pitkänen et al., 2001) or landbased sources, i.e. river estuaries or sewage pipelines (Piirsoo, 1982; Porgassaar, 1982).

In the north-eastern Baltic Sea the dominating benthic invertebrates feed mainly on seston, i.e. small free-floating organisms and lifeless particles (Yarvekyulg, 1979). In shallow waters the benthic suspension feeders are the main consumers of phytoplankton (Kotta \& Møhlenberg, 2002) whereas the deposit feeding invertebrates rely on the sedimented phytoplankton in the deeper sea (Kube et al.,

* Corresponding author, jonne@sea.ee 
1996; Lehtonen \& Andersin, 1998). The addition of nutrients stimulates phytoplankton growth, which in turn provides better dietary conditions for both benthic suspension and deposit feeders (Levinton, 1995).

Large-scale quantitative macrozoobenthos research in the Estonian coastal sea dates back to 1959 (Ojaveer et al., 2000). Since then the macrozoobenthos around the whole coast has been mapped every decade and at some sites at higher frequency. Based on the existing data we defined the areas where the benthic biomasses and abundances were constantly higher than in the adjacent sea despite similar bottom topography and sediment characteristics (Fig. 1). These areas may broadly be divided into three groups - hydrologically active areas or upwelling areas, sites adjacent to municipal discharges and river estuaries.

The aim of the present study is to describe the benthic communities in the areas of elevated productivity of the Estonian coastal sea. The spatial and temporal variability in the species number, abundance, and biomass structure of macrozoobenthos are related to the concentration of nutrients in the seawater. The data on the spatial and temporal variation of benthic invertebrate assemblages and water nutrients were obtained from the available literature and the database of the Estonian Marine Institute. The database covers the major bays of the Estonian coastal sea from the early 1950 s to the present time.

\section{HYDROLOGICALLY ACTIVE AREAS}

Two different types of hydrologically active areas may be distinguished in the Estonian coastal sea: upwelling areas and the fronts between different subbasins. The representatives of the former type include the sea areas adjacent to Osmussaar and Kihnu shallows. All these areas are characterized by a steep bank slope, which forms a barrier to the prevalent nearbottom currents and, hence, results in daily upwelling. The latter type is often found in the Väinameri and at the Irbe Strait. As a result of the mixing of different water masses the nutrients from deep water are transported to the surface layer supporting higher pelagic (Oyaveer \& Kalejs, 1974; Kahru et al., 1984) and consequently benthic production (Yarvekyulg, 1979). Both types of hydrologically active areas are ranked as important fishery grounds reflecting their high productivity (Oyaveer \& Kalejs, 1974).

Macrozoobenthos of the Osmussaar area was studied between 1950 and 2001 (Yarvekyulg, 1979; Kotta et al., 1999; Kotta, J. \& Kotta, I., 1999). During this period higher biomasses were regularly observed in the strait between Osmussaar Island and the mainland, including in the area north of Nõva and Keibu bays (Fig. 1). In these sites the average number of species was relatively high reaching up to 12 taxa at $30 \mathrm{~m}$. The dominant species were the filter-feeding bivalve Mytilus edulis and the deposit-feeding bivalve Macoma balthica. The filterfeeders were more abundant in the upwelling areas where high phytoplankton production supported the persistence of their dense population. The depositfeeders were more abundant in the sedimentation areas where slow currents and finer bottom substrate favoured the development of their abundant community. 


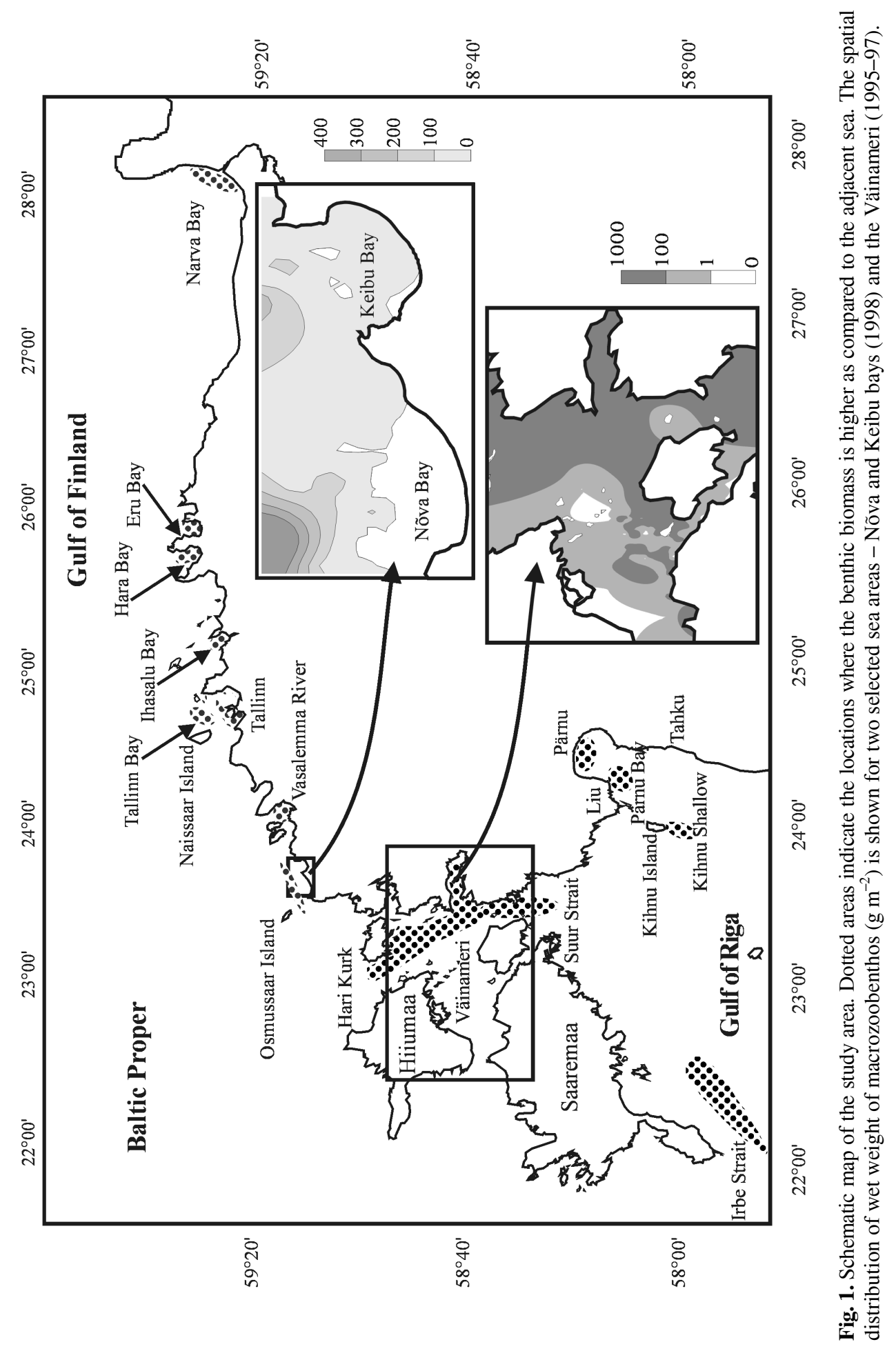


In these hydrodynamically active areas the average biomass of macrozoobenthos was $195 \mathrm{~g} \mathrm{ww} \mathrm{m}^{-2}$ prior to 1995 and only $60 \mathrm{~g} \mathrm{ww} \mathrm{m}^{-2}$ in 1997-2001 (Fig. 2). In adjacent areas the biomass rarely exceeded $140 \mathrm{~g} \mathrm{ww} \mathrm{m}^{-2}$ with average at $75 \mathrm{~g} \mathrm{ww} \mathrm{m}^{-2}$ prior to 1995 and $46 \mathrm{~g} \mathrm{ww} \mathrm{m}^{-2}$ in 1997-2001 (Kotta et al., 1999). The species number increased significantly from 1994 to 1999 followed by a notable decline afterwards. There was no clear relationship between the macrozoobenthos biomass and the species number. No significant correlation was found between the total $\mathrm{P}$ concentration and macrozoobenthos biomass in the 1990s $(p>0.05)$. However, the benthic biomass increased significantly with total $\mathrm{N}$ in water $(r=0.85, p<0.001)$, which supports the earlier findings that nitrogen is a limiting factor for producers in the Gulf of Finland (Suursaar, 1992). Hence, the decline in the macrozoobenthos biomass in the 1990s reflects the notable
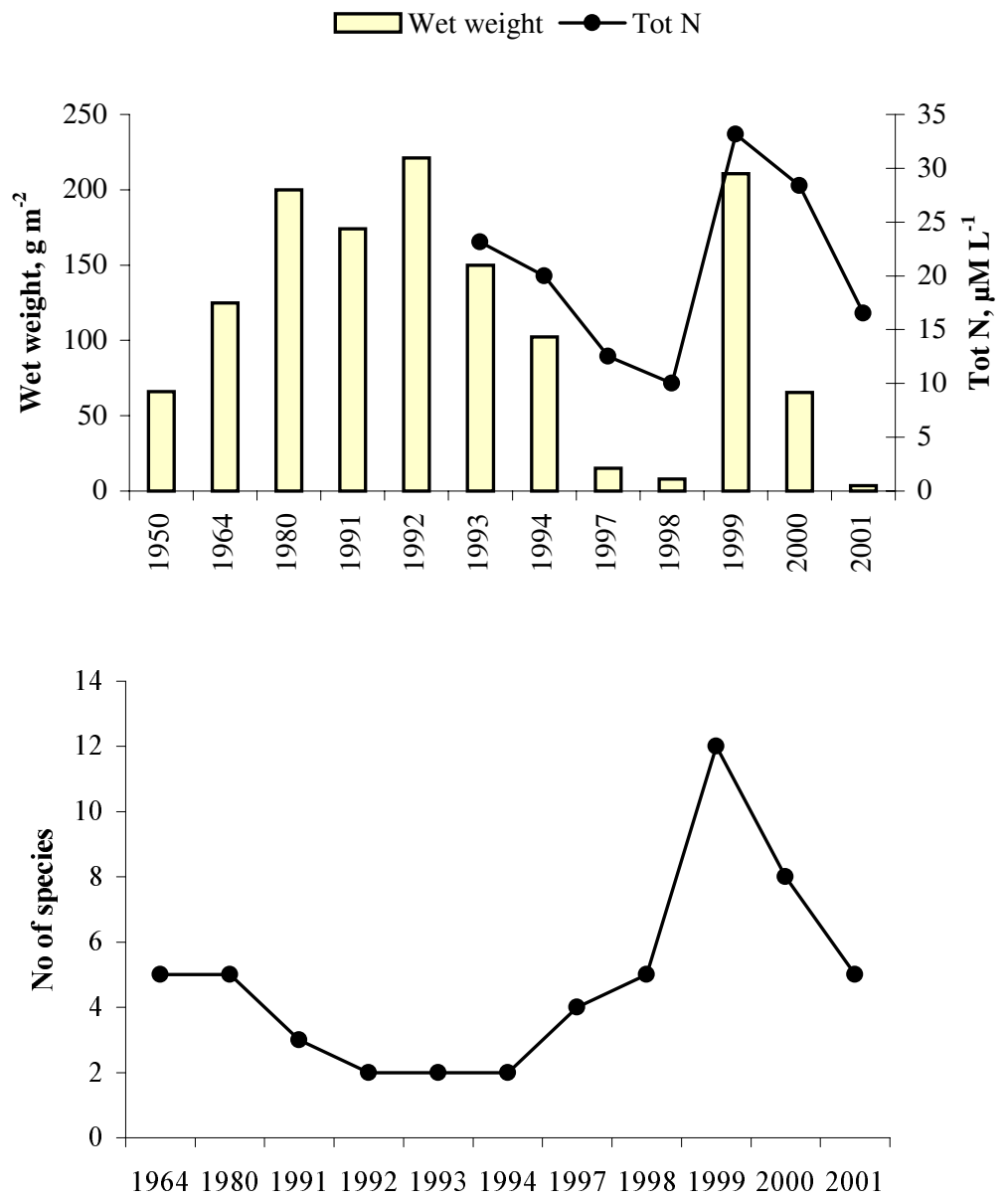

Fig. 2. Temporal changes in macrozoobenthos wet weight, total $\mathrm{N}$ in water (measured in winter), and species number at a $30 \mathrm{~m}$ station in the Osmussaar area. 
reduction in the nurient load in the Gulf of Finland. This decrease was probably a consequence of the intensified purification of wastewaters from forestry and municipalities. Besides, the weakening of the halocline has resulted in an improvement of oxygen conditions at the bottom and has reduced internal nutrient loads (HELCOM, 1996, 2002; Pitkänen et al., 2001).

Similarly to zoobenthos, nektobenthos concentrates towards the upwelling areas. There exists some evidence that higher densities of mysids often occur on steep slopes where strong gradients in temperature are observed (Kotta, I. \& Kotta, J., 1999; Kotta \& Kotta, 2001). Kihnu Island and the shallows in its vicinity are a natural hindrance to the deep water currents of the Gulf of Riga (Lips et al., 1995). Consequently, a sharp thermocline lying between 15 and $20 \mathrm{~m}$ was observed on the Kihnu transect during June 1977-80. The abundance values of mysids were relatively low both in the shallowest and deepest parts of the bank slopes. Significantly higher abundance values were observed in the areas where the thermocline touched the bottom (Fig. 3). The occurrence of mysids in the vicinity of the temperature discontinuity layer indicates that mysids perform horizontal migrations following the displacement of the thermocline. Different species of mysids aggregated towards the temperature discontinuity layer regardless of their temperature preference, i.e. cold stenotherms were found in warm water and vice versa. It is likely that the distribution of phytoplankton and zooplankton determines the distribution pattern of mysids. Earlier studies have reported higher phytoplankton densities in hydrodynamically active areas
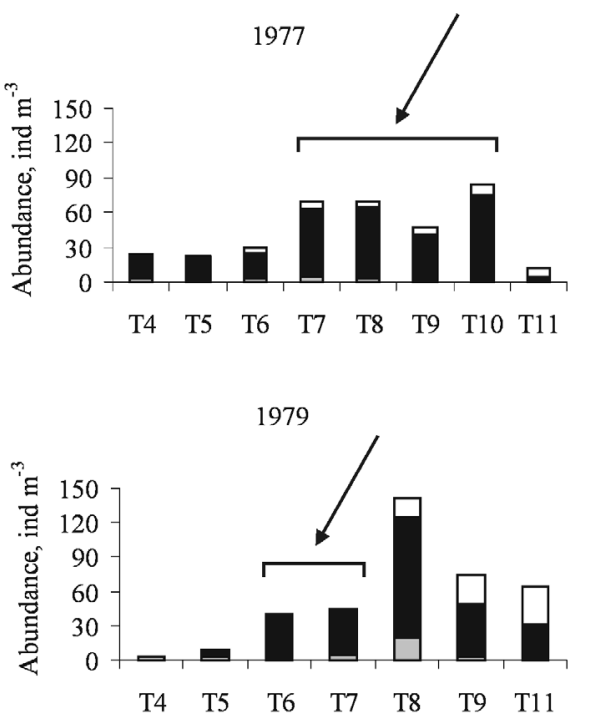

$\square$ N. integer

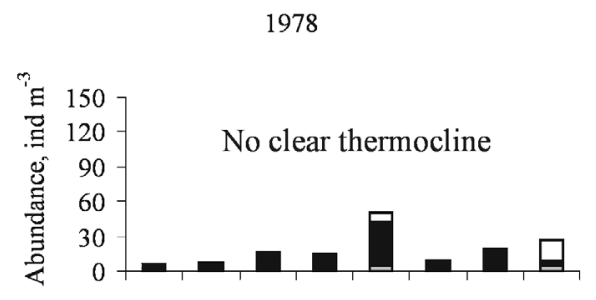

$\begin{array}{lllllllll}\text { T4 } & \text { T5 } & \text { T6 } & \text { T7 } & \text { T8 } & \text { T9 } & \text { T10 } & \text { T11 }\end{array}$

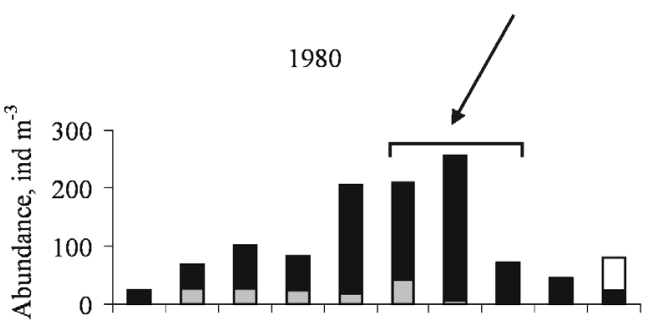

$\begin{array}{llllllllll}\mathrm{T} 1 & \mathrm{~T} 2 & \mathrm{~T} 3 & \mathrm{~T} 4 & \mathrm{~T} 5 & \mathrm{~T} 6 & \mathrm{~T} 7 & \mathrm{~T} 8 & \mathrm{~T} 9 & \mathrm{~T} 11\end{array}$

Fig. 3. Abundance distribution of mysids on the bank slope adjacent to Kihnu Shallow (stations T1-T11) in 1977-80. Arrows indicate the locations where the mixing of deep and surface water occurs. 
(Kahru et al., 1984; Kononen et al., 1996). This, in turn, supports higher zooplankton (Ojaveer \& Simm, 1975) and, hence, their predator, mysids' densities (Kinne, 1955; Arndt \& Jansen, 1986; Rudstam \& Hansson, 1990).

Besides upwelling areas described above, the feeding conditions are favourable in the areas where waters of different subbasins meet. In the Irbe Strait water exchange takes place between the Gulf of Riga and the Baltic Proper (Berzinsh, 1995; Lips et al., 1995). The area was characterized by very high benthic biomasses (Fig. 4; Yarvekyulg, 1979). Similarly to the Osmusaar area a slight decrease in the macrozoobenthos biomass was observed since 1997. The biomass of macrozoobenthos was positively correlated with total $\mathrm{N}$ in the nearbottom water $(r=0.83, p<0.001)$. Neither the concentrations of nutrients nor the biomass correlated with the species number of macrozoobenthos $(p>0.05)$. The deposit-feeder M. balthica comprised the bulk of the biomass. The abundance of
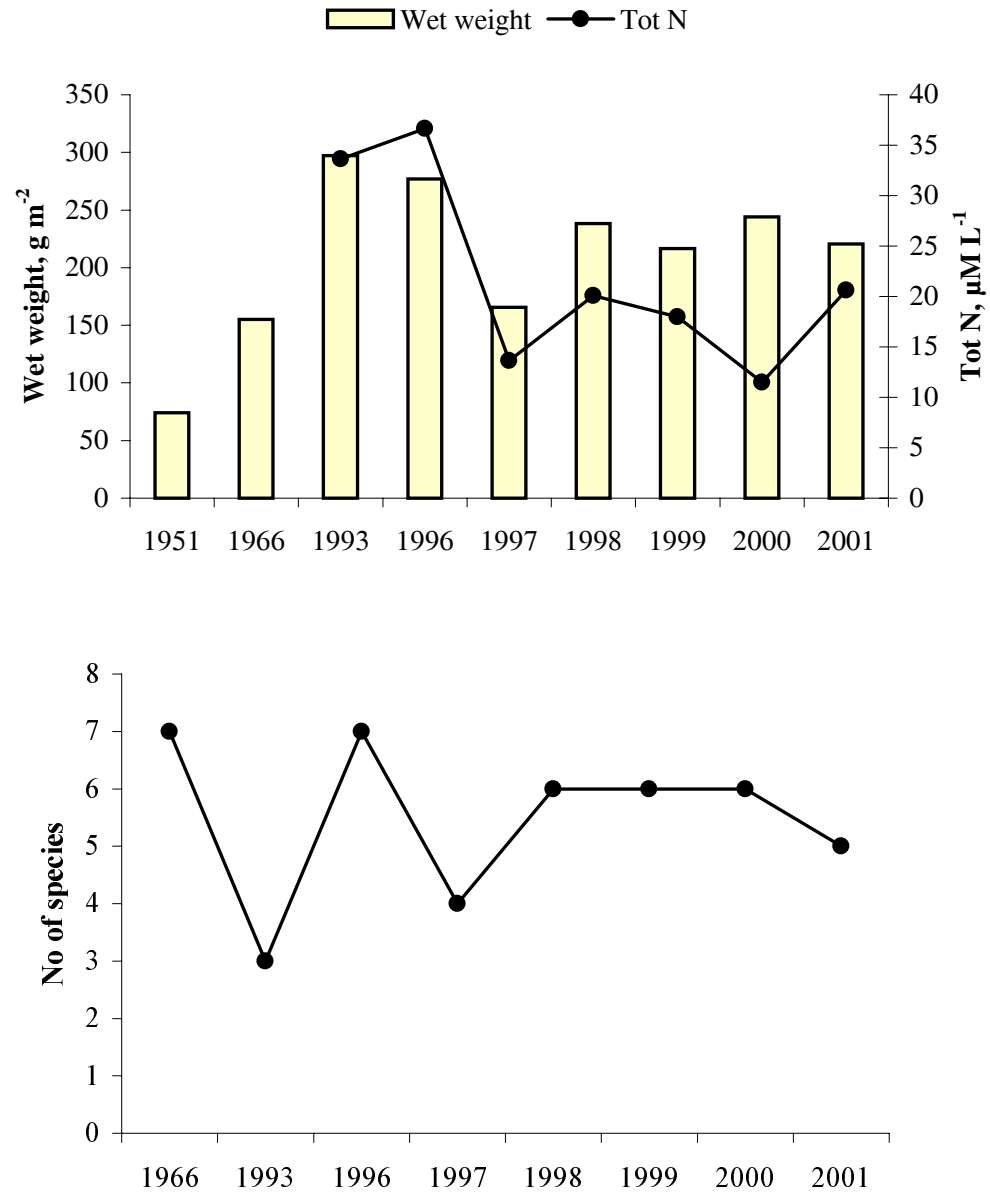

Fig. 4. Temporal changes in macrozoobenthos wet weight, total $\mathrm{N}$ in water (measured in winter), and species number at a $30 \mathrm{~m}$ station in the Irbe Strait. 
nektobenthic mysids was very high in the studied strait in summers 1974-75 (Kotta, I. \& Kotta, J., 1999). During this mapping study such high mysid densities were observed only in heavily polluted Pärnu Bay and in the sea adjacent to the Daugava River.

Intensive water exchange between the Gulf of Riga, the Gulf of Finland, and the Baltic Proper takes place through the Väinameri (Suursaar et al., 1998). The entire area is shallow, the depths are mostly less than $10 \mathrm{~m}$. This makes the importance of benthic macroalgae in the dynamics of macrozoobentos high. An extensive part of the Väinameri is covered by a unique assemblage of the looselying macroalga Furcellaria lumbricalis (Trei, 1970; Kotta \& Orav, 2001).

The benthic biomass was very high in the Väinameri prior to 1998 (Figs. 1, 5; Järvekülg, 1970, 1985; Yarvekyulg, 1979). Since then a notable decline in the
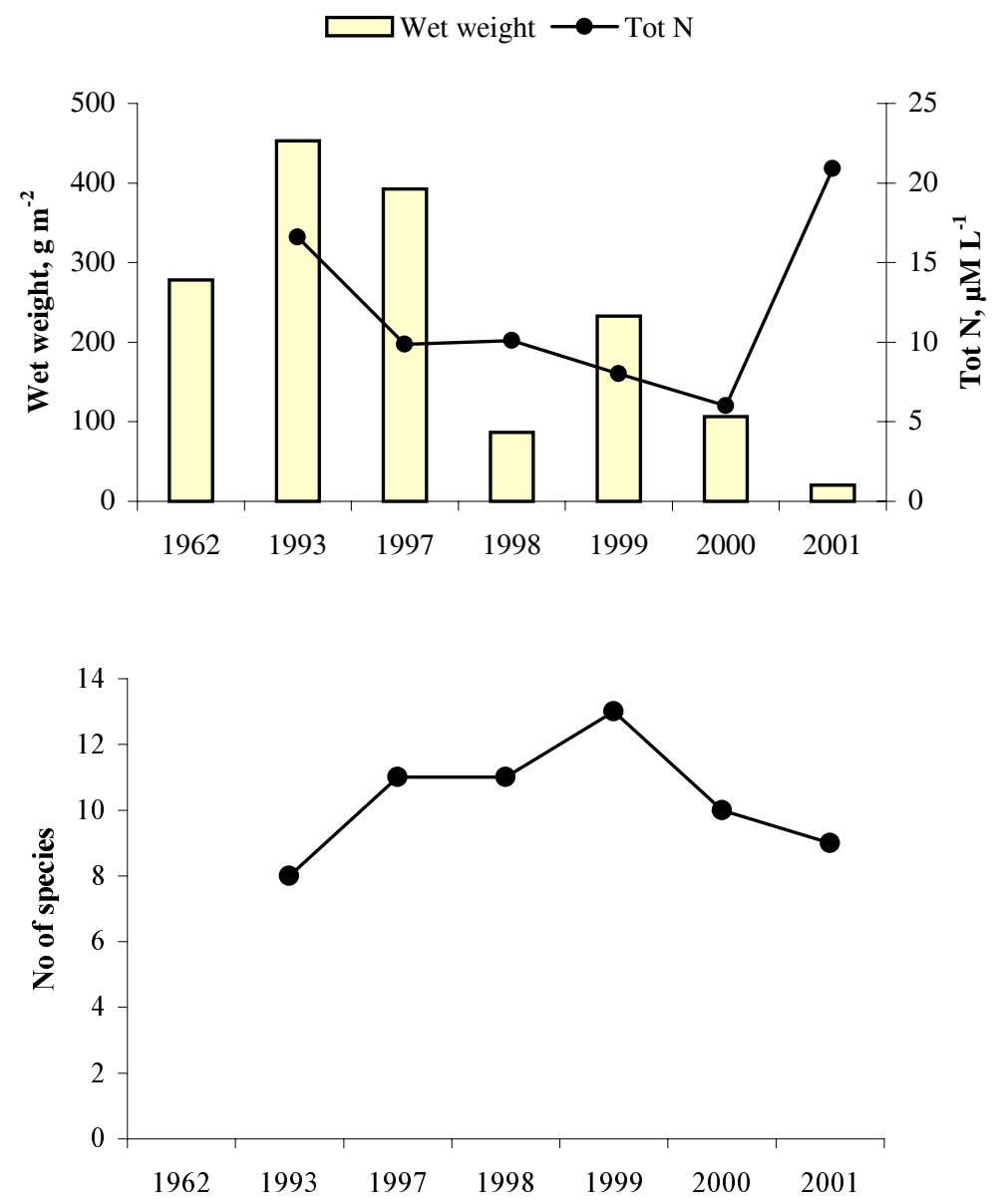

Fig. 5. Temporal changes in macrozoobenthos wet weight, total $\mathrm{N}$ in water (measured in winter), and species number at a $7 \mathrm{~m}$ station in the Väinameri. 
biomass was observed. It is likely that most of the macrozoobenthos does not rely on pelagic food in the Väinameri as indicated by the weak correlation between the concentration of nutrients and the benthic biomass $(r=0.04$, $p>0.05)$. F. lumbricalis, an important primary producer in the system, contributes significantly to the diet of macrozoobenthos, for example Gammarus spp. and Idotea spp. (Orav-Kotta \& Kotta, 2003). Besides amphipods, the area has dense populations of the bivalves M. edulis, Mya arenaria, and M. balthica (Orav et al., 2000; Kotta \& Orav, 2001), which can consume either pelagic or benthic microalgae.

\section{AREAS ADJACENT TO MUNICIPAL SEWAGE DISCHARGES}

Tallinn Bay is the most polluted area in the Estonian coastal sea. During the last 40 years the water quality of the area has been strongly affected by the input of pollutants from land based sources (Turro \& Jakobson, 1997). In the 1960s, when large quantities of untreated wastewater were directly discharged into the bay, benthic invertebrates were missing or had very low biomasses in wide areas at depths between 0.5 and $15 \mathrm{~m}$ (Fig. 6; Yarvekyulg, 1979; Yarvekyulg \& Seire, 1983). Below $15 \mathrm{~m}$, on the contrary, very high biomasses of $M$. balthica, Cerastoderma glaucum, M. edulis, M. arenaria, and Hediste diversicolor were recorded.

The majority of coastal discharges were stopped and a deep water collector was put into operation in 1978. The water has been treated mechanically since 1979 and biologically since the late 1980s. At the beginning of the 1990s Tallinn Pulp and Paper Mill was closed, which further improved the water quality of Tallinn Bay (Turro \& Jakobson, 1997).

In the 1990s the lifeless zone (as to macrozoobenthos) disappeared from the shallow areas of Tallinn Bay (Fig. 6). The biomass values of macrozoobenthos did not differ significantly from the adjacent bays of lower nutrient loads, for example Kakumäe and Muuga bays. Both the number of species and biomass increased with depth. Bivalves were still the dominating group among benthos. During 30 years the benthic biomass declined about 3-4 times. The changes were mainly due to the decline of the biomass of bivalves.

Together with macrozoobenthos benthic vegetation has improved in Tallinn Bay in recent years. Fucus vesiculosus is nowadays found in the areas where it did not occur in previous decades (Martin \& Kukk, 1997). The increase in the biomass of macrophytobenthos has had a positive effect on the nektobenthic crustaceans. Various phytophilous species, for example Gammarus spp., Jaera albifrons, Idotea baltica, and I. viridis, were found around the whole coastal sea of Tallinn Bay in 2001.

In the 1990s the benthic biomass was still high in the areas directly influenced by the discharges of the deep water pipeline. The biomass exceeded $1 \mathrm{~kg} \mathrm{ww} \mathrm{m}{ }^{-2}$ in these areas. High benthic biomasses in Kopli Bay reflected its previous strong 

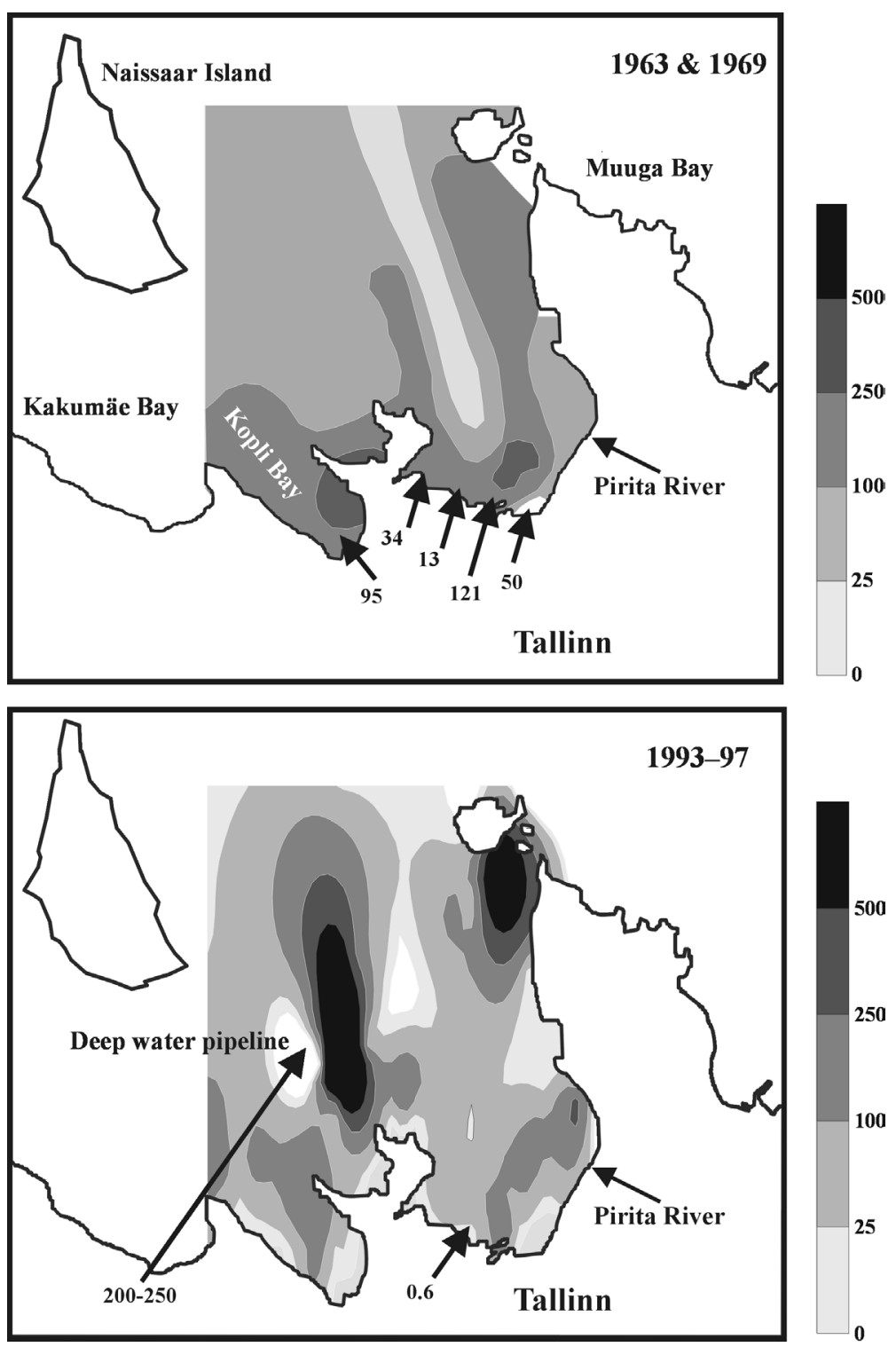

Fig. 6. Spatial distribution of the wet weight of macrozoobenthos in Tallinn Bay in the 1960s and $1990 \mathrm{~s}$. The location of wastewater outputs and diel average discharges in $\mathrm{m}^{3}$ per day are indicated by arrows.

contamination. The nutrient load into Kopli Bay was the highest in the whole Tallinn Bay area in the 1970s and 1980s (Turro \& Jakobson, 1997).

At $80 \mathrm{~m}$ depth we observed a clear negative effect of the discharged effluents on the benthic communities (Fig. 7). When the total phosphorus concentration in 
1993-2000

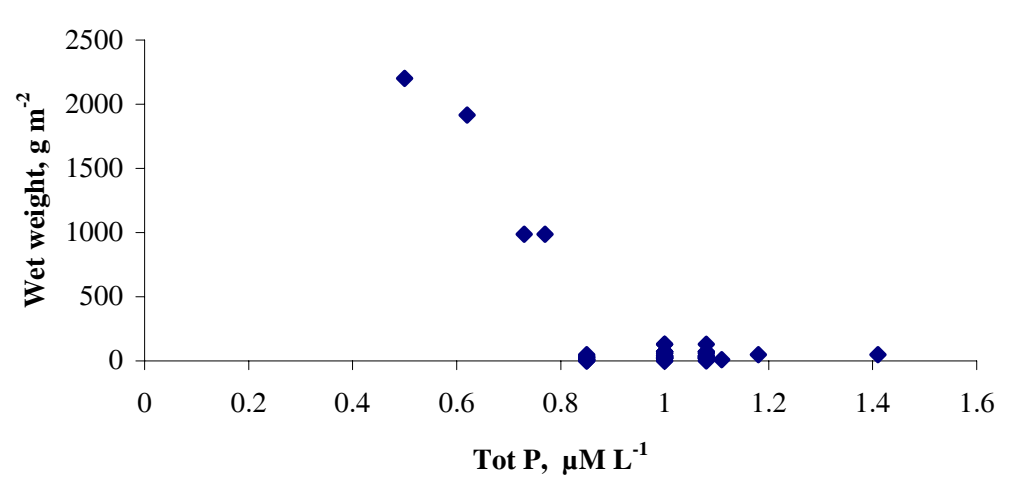

Fig. 7. Relationship between total $\mathrm{P}$ in water (measured in winter) and macrozoobenthos wet weight at a $80 \mathrm{~m}$ station in Tallinn Bay.

water rose above $0.8 \mu \mathrm{M}^{-1}$ the biomass of macrozoobenthos declined abruptly. Increased nutrient concentrations are likely coupled with higher inputs of organic matter and, hence, increased oxygen consumption in the sediment. This is also indicated by a strong negative correlation between the nutrient level and the oxygen concentration in this site $(r=0.70, p<0.01)$. Decreased oxygen concentrations make conditions for most benthic invertebrates unbearable (Leppäkoski, 1975; Warzocha, 1994; Sandberg, 1996), which explains the collapse of macrozoobenthos in the area.

\section{AREAS ADJACENT TO RIVERMOUTHS}

Macrozoobenthos communities at most rivermouths of the Gulf of Finland did not differ from those of the neighbouring areas. As compared to the adjacent sea higher macrozoobenthos biomass and diversity were recorded at the mouths of the Loobu, Valgejõgi, Jägala, and Narva rivers, i.e. in Eru, Hara, Ihasalu, and Narva bays, respectively (Fig. 8). In these rivermouths substantially higher concentrations of nutrients were observed (Suursaar, 1992). Despite relatively small water discharges of the first three rivers, the respective bays show high diversity and biomass values due to the isolation of the bay and weak sea currents. Narva Bay, on the contrary, is exposed and the effect of strong sea currents is compensated for by very large quantities of outflowing river water. In recent decades the biomass of macrozoobenthos has increased and the number of species has remained unchanged at the mouths of the Loobu, Valgejõgi, and Jägala rivers. At the mouth of the Narva River, however, both benthic diversity and biomass have decreased. 

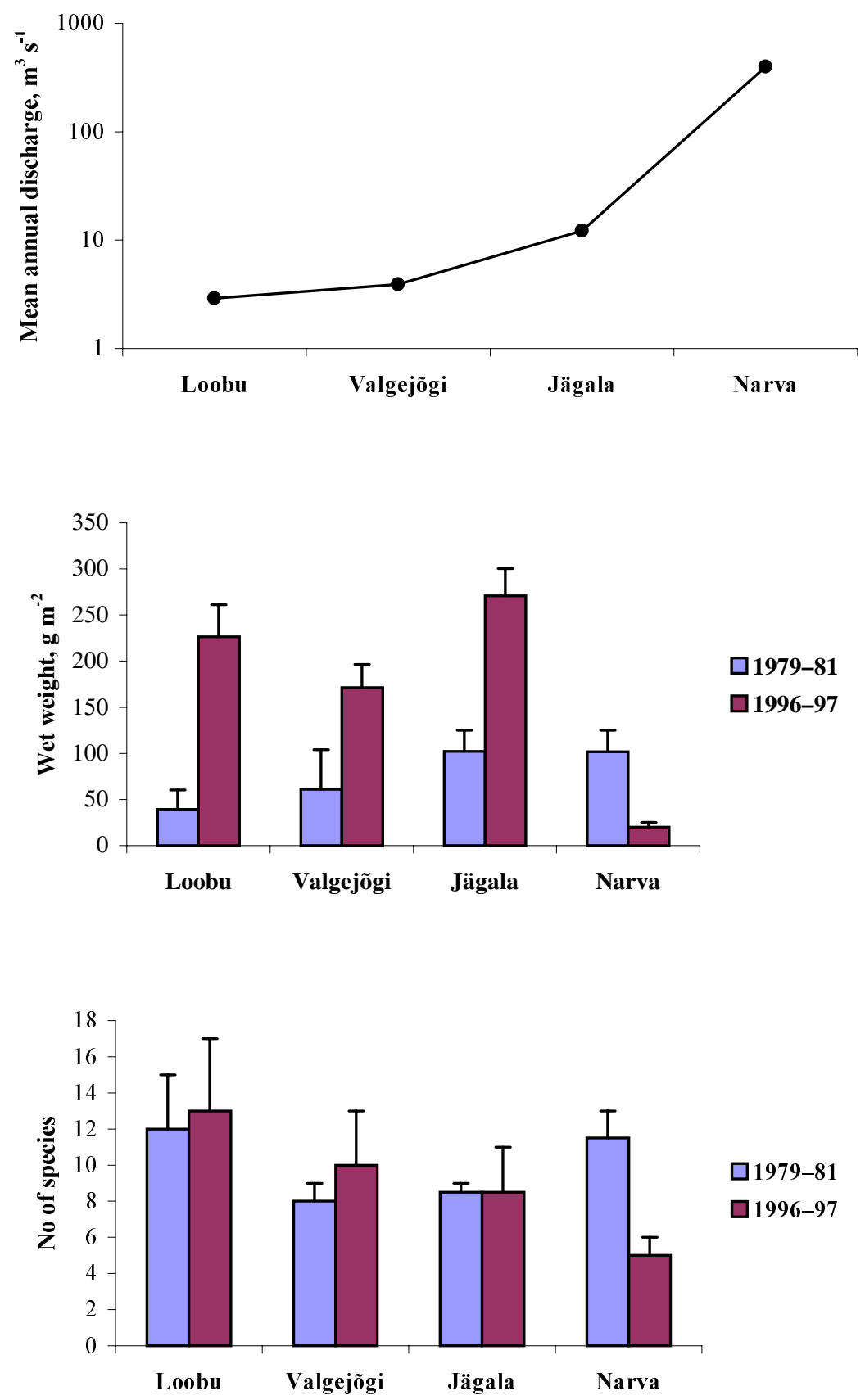

Fig. 8. The mean annual discharge of rivers (Pachel, 1993), wet weight of macrozoobenthos, and number of species ( \pm SE) at different rivermouths in the Gulf of Finland in the 1980s and 1990s. 
The impoverishment of the benthic communities in Narva Bay is in accordance with the reduction of the nutrient load into the Gulf of Finland in the 1990s (HELCOM, 1996, 2002). The increase in the benthic biomass in the remaining three rivermouths is likely connected to the mass development of benthic filamentous algae in the Estonian coastal sea in the 1990s (Kotta et al., 2000). The lack of these blooms in Narva Bay is related to the scarcity of suitable hard substrate in the area.

The effect of the Pirita River on macrozoobenthos was not detectable in the 1960s and 1970s due to stronger landbased pollution loads from other sources. Nowadays the sea adjacent to the Pirita rivermouth has higher biomasses than average in the coastal area of Tallinn Bay (Fig. 6).

There are almost no areas from which the organic load from rivers has wiped out macrozoobenthos in the Estonian coastal sea. The mouth of the Vasalemma River is one of the few examples. The accumulation of hydrogen sulphide in the sediment allowed only nektobenthic invertebrates to temporarily colonize the area.

The Gulf of Riga is more strongly influenced by the riverine input than the Gulf of Finland. This is due to the stronger isolation and extensive shallow areas in the former. In the late 1950s the effect of the Pärnu River on macrozoobenthos was not clear. The highest biomasses were observed in the outer part of Pärnu Bay (Fig. 9; Järvekülg, 1960). Since 1960 the macrozoobenthos biomass has gradually increased in the bay with higher values close to the mouth of the Pärnu River. Maximum densities were estimated at 20500 ind. $\mathrm{m}^{-2}$ and biomass at $600 \mathrm{~g} \mathrm{ww} \mathrm{m}^{-2}$ in 1991. Corophium volutator and M. balthica accounted for more than $90 \%$ of the macrozoobenthos density. M. balthica dominated in biomass (Kotta \& Kotta, 1995).

Since the late 1980s the density of the nektobenthic mysid Neomysis integer has increased manifold in Pärnu Bay (Kotta, 1995; Kotta et al., 2003). This change was most likely triggered by the increased contamination of the bay with nutrients originating from municipal and agricultural discharges. As a result the content of tot-N, tot-P, and silicate increased on average two times in the seawater and the primary production of phytoplankton increased substantially in the 1970s and 1980s (Ojaveer, 1995; Tenson, 1995).

Following the economic recession of Estonia in the 1990s macrobenthic biomass declined significantly. During the recession the intensity of agriculture was substantially reduced resulting in a decline of the nutrient content in the seawater (Suursaar, 1995). However, since 2000 the concentration of nutrients and macrozoobenthos biomass have been gradually increasing (Fig. 10). The dependence of macrozoobenthos biomass on nutrients is indicated by significant correlations between the biomass and total $\mathrm{N}(r=0.93, p<0.001)$ and total $\mathrm{P}$ values in water $(r=0.52, p<0.01)$. With the increase in nutrient concentrations C. volutator, M. balthica, and Oligochaeta increased while Prostoma obscurum, Hydrobia ulvae, and $H$. ventrosa decreased their density. 

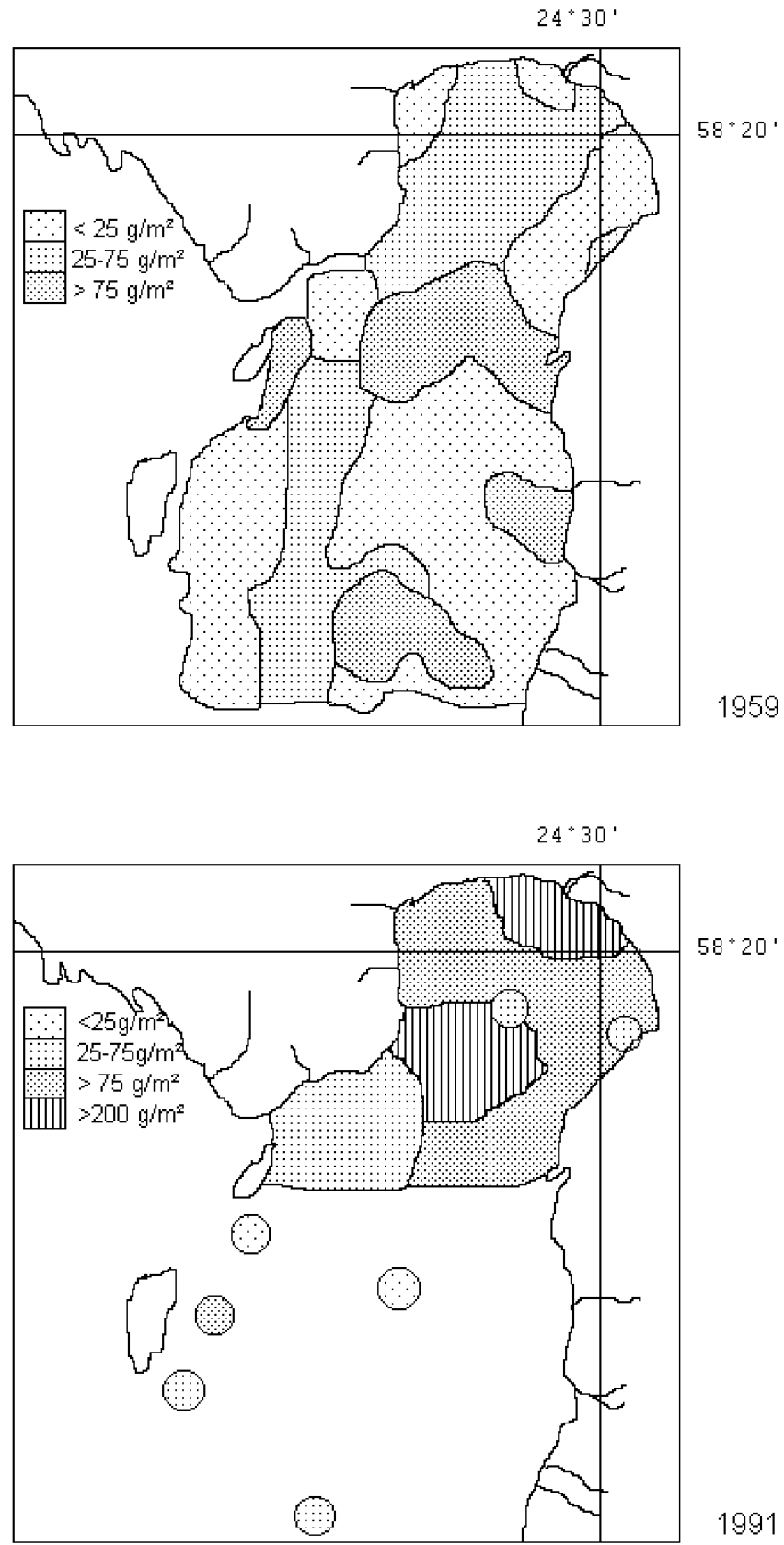

Fig. 9. Spatial distribution of the wet weight of macrozoobenthos in Pärnu Bay in 1959 and 1991 (Kotta \& Kotta, 1995). 

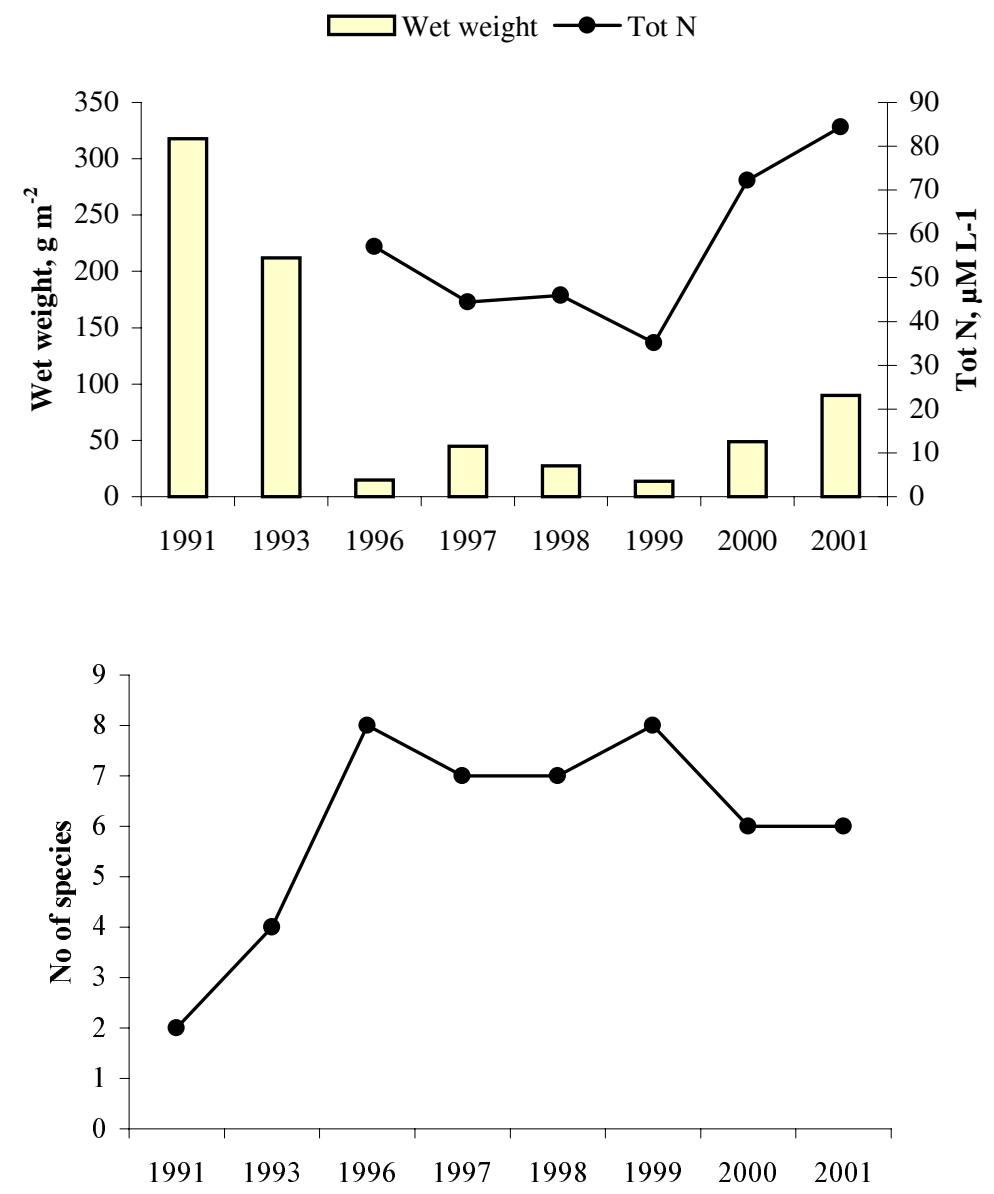

Fig. 10. Temporal changes in macrozoobenthos wet weight, total $\mathrm{N}$ in water (measured in winter), and species number at a $5 \mathrm{~m}$ station in Pärnu Bay.

\section{ACKNOWLEDGEMENTS}

This study was financed by the Estonian Governmental Programmes Nos. 0200792s98, 0200797s98, and 0182578s03, the Estonian Science Foundation grant No. 5103, and the EU CHARM project.

\section{REFERENCES}

Arndt, E. A. \& Jansen, W. 1986. Neomysis integer (Leach) in the chain of boddens south of Darss/ Zingst (Western Baltic) - ecophysiology and population dynamics. Ophelia Suppl., 4, 1-15. Berzinsh, V. 1995. Hydrological regime. In Ecosystem of the Gulf of Riga between 1920 and 1990 (Ojaveer, E., ed.), pp. 7-31. Estonian Acad. Publ., Tallinn. 
HELCOM, 1996. Third periodic assessment of the state of the marine environment of the Baltic Sea, 1989-1993; Background document. Balt. Sea Environ. Proc., No. 64B.

HELCOM, 2002. Environment of the Baltic Sea area 1994-1998. Balt. Sea Environ. Proc., No. $82 \mathrm{~B}$.

Järvekülg, A. 1960. Materjale Pärnu lahe põhjaloomastiku kohta. Eesti NSV TA Toim. Biol., 9, 199_ 214.

Järvekülg, A. 1970. Väinamere põhjaloomastik. In Lääne-Eesti rannikualade loodus (Kumari, E., ed.), pp. 42-60. Valgus, Tallinn.

Järvekülg, A. 1985. Matsalu lahe põhjaloomastik. In Matsalu - rahvusvahelise tähtsusega märgala (Kumari, E., ed.), pp. 53-76. Valgus, Tallinn.

Kahru, M., Elken, J., Kotta, I., Simm, M. \& Vilbaste, K. 1984. Plankton distributions and processes across a front in the open Baltic Sea. Mar. Ecol. Prog. Ser., 20, 101-111.

Kinne, O. 1955. Neomysis vulgaris Thompson, eine autökologisch-biologische Studie. Biol. Zentralbl., 74, 160-202.

Kononen, K., Kuparinen, J., Mäkelä, K., Laanemets, J., Pavelson, J. \& Nõmmann, S. 1996. Initiation of cyanobacterial blooms in a frontal region at the entrance to the Gulf of Finland, Baltic Sea. Limnol. Oceanogr., 41, 98-112.

Kotta, I. 1995. Nektobenthos (Mysidacea). In Ecosystem of the Gulf of Riga between 1920 and 1990 (Ojaveer, E., ed.), pp. 187-195. Estonian Acad. Publ., Tallinn.

Kotta, I. \& Kotta, J. 1999. Distribution and migration of mysids in the Gulf of Riga (northern Baltic). Proc. Estonian Acad. Sci. Biol. Ecol., 48, 284-295.

Kotta, I. \& Kotta, J. 2001. Distribution of mysids on bank slopes in the Gulf of Riga. Proc. Estonian Acad. Sci. Biol. Ecol., 50, 14-21.

Kotta, J. \& Kotta, I. 1995. The state of macrozoobenthos of Pärnu Bay in 1991 as compared to 1959-1960. Proc. Estonian Acad. Sci. Ecol., 5, 26-37.

Kotta, J. \& Kotta, I. 1999. Benthic animal communities around Osmussaar Island. Est. Marit., 4, $133-142$.

Kotta, J. \& Møhlenberg, F. 2002. Grazing impact of Mytilus edulis and Dreissena polymorpha (Pallas) in the Gulf of Riga, Baltic Sea estimated from biodeposition rates of algal pigments. Ann. Zool. Fenn., 39, 151-160.

Kotta, J. \& Orav, H. 2001. Role of benthic macroalgae in regulating macrozoobenthic assemblages in the Väinameri (north-eastern Baltic Sea). Ann. Zool. Fenn., 38, 163-171.

Kotta, J., Kotta, I. \& Kask, J. 1999. Benthic animal communities of exposed bays in the western Gulf of Finland (Baltic Sea). Proc. Estonian Acad. Sci. Biol. Ecol., 48, 107-116.

Kotta, J., Paalme, T., Martin, G. \& Mäkinen, A. 2000. Major changes in macroalgae community composition affect the food and habitat preference of Idotea baltica. Internat. Rev. Hydrobiol., 85, 693-701.

Kotta, J., Simm, M., Kotta, I., Kanošina, I., Kallaste, K. \& Raid, T. 2003. Factors controlling the long-term changes of the eutrophicated ecosystem of Pärnu Bay, the Gulf of Riga. Hydrobiologia, in press.

Kube, J., Powilleit, M. \& Warzocha, J. 1996. The importance of hydrodynamic processes and food availability for the structure of macrofauna assemblages in the Pomeranian Bay (southern Baltic Sea). Arch. Hydrobiol., 138, 213-228.

Le Fèvre, J. 1986. Aspects of the biology of frontal systems. Adv. Mar. Biol., 23, 163-299.

Lehtonen, K. \& Andersin, A.-B. 1998. Population dynamics, response to sedimentation and role in benthic metabolism of the amphipod Monoporeia affinis in an open-sea area of the northern Baltic Sea. Mar. Ecol. Prog. Ser., 168, 71-85.

Leppäkoski, E. 1975. Assessment of the degree of pollution on the basis of macrozoobenthos in marine and brackish-water environments. Acta Acad. Abo., Ser. B, Mat. naturvetensk. tek., 35(2), 1-90.

Levinton, J. S. 1995. Marine Biology. Function, Biodiversity, Ecology. Oxford Univ. Press, New York, Oxford. 
Lips, U., Lilover, M.-J., Raudsepp, U. \& Talpsepp, L. 1995. Water renewal processes and related hydrographic structures in the Gulf of Riga. EMI Rep. Ser., 1, 1-34.

Martin, G. \& Kukk, H. 1997. Benthic littoral vegetation as an indicator of the eutrophication situation in the coastal urban area of Tallinn Bay. EMI Rep. Ser., 8, 1-10.

Ojaveer, E. 1995. Large-scale processes in the ecosystem of the Gulf of Riga. In Ecosystem of the Gulf of Riga between 1920 and 1990 (Ojaveer, E., ed.), pp. 268-277, Estonian Acad. Publ., Tallinn.

Ojaveer, E. \& Simm, M. 1975. Effect of zooplankton abundance and temperature on time and place of reproduction of Baltic herring groups. Merentutkimuslait. Julk., 239, 139-145.

Ojaveer, E., Rannak, L. \& Laevastu, T. 2000. One and a Half Centuries of Sea and Fisheries Investigations in Estonia. Estonian Acad. Publ., Tallinn.

Orav, H., Kotta, J. \& Martin, G. 2000. Factors affecting the distribution of benthic invertebrates in the phytal zone of the north-eastern Baltic Sea. Proc. Estonian Acad. Sci. Biol. Ecol., 49, 253-269.

Orav-Kotta, H. \& Kotta, J. 2003. Seasonal variations in the grazing of Gammarus oceanicus, Idotea baltica, and Palaemon adspersus on benthic macroalgae. Proc. Estonian Acad. Sci. Biol. Ecol., 52, 141-148.

Oyaveer, E. A. \& Kalejs, M. V. 1974. On some oceanographic factors determining the abundance and distribution of pelagic fish in the Baltic Sea. Okeanologiya, 14, 544-554 (in Russian).

Pachel, K. 1993. The state of rivers. Hydrological survey. In Water Pollution and Quality in Estonia (Pylvänäinen, M., ed.), pp. 5-10. Environment Data Centre, National Board of Waters and the Environment, Helsinki.

Piirsoo, K. 1982. Saastumise mõju Eesti NSV rannikumere fütoplanktoni liigilisele koosseisule ja biomassile. In Eesti NSV rannikumere kaitse (Järvekülg, A., ed.), pp. 49-52. Valgus, Tallinn.

Pitkänen, H., Lehtoranta, J. \& Räike, A. 2001. Internal nutrient fluxes counteract decreases in external load: the case of the estuarial Eastern Gulf of Finland, Baltic Sea. Ambio, 30, 195-201.

Porgassaar, V. 1982. Hapniku-, fosfori- ja klorofüllisisaldus Eesti NSV rannikumere eutrofeerunud piirkondades. In Eesti NSV rannikumere kaitse (Järvekülg, A., ed.), pp. 40-45. Valgus, Tallinn.

Rudstam, L. G. \& Hansson, S. 1990. On the ecology of Mysis mixta (Crustacea, Mysidacea) in a coastal area of the northern Baltic proper. Ann. Zool. Fenn., 27, 259-263.

Sandberg, E. 1996. Benthic predator-prey relationships and abiotic stress - the effects of physical disturbance and oxygen deficiency. Doctoral dissertation, Åbo Akademi University, Åbo Akademi Tryckeri, Åbo.

Suursaar, Ü. 1992. The state of the Estonian coastal waters in 1979-1990: seasonal, vertical, and horizontal variations. Proc. Estonian Acad. Sci. Ecol., 2, 129-136.

Suursaar, Ü. 1995. Nutrients in the Gulf of Riga. In Ecosystem of the Gulf of Riga between 1920 and 1990 (Ojaveer, E., ed.), pp. 41-50. Estonian Acad. Publ., Tallinn.

Suursaar, Ü., Astok, V. \& Otsmann, M. 1998. The front of Väinameri. EMI Rep. Ser., 9, 23-33.

Tenson, J. 1995. Phytoplankton of the Pärnu Bay. In Ecosystem of the Gulf of Riga between 1920 and 1990 (Ojaveer, E., ed.), pp. 104-126. Estonian Acad. Publ., Tallinn.

Trei, T. 1970. Väinamere põhjataimestik. In Lääne-Eesti rannikualade loodus (Kumari, E., ed.), pp. 27-41. Valgus, Tallinn.

Turro, A. \& Jakobson, I. 1997. Dynamics of pollution from point sources in Tallinn Bay. EMI Rep. Ser., 8, 73-83.

Warzocha, J. 1994. Spatial distribution of macrofauna in the southern Baltic in 1983. Bull. Sea Fish. Inst. Gdynia, 131, 47-59.

Yarvekyulg, A. 1979. Bottom Fauna in the Eastern Part of the Baltic Sea. Valgus, Tallinn (in Russian).

Yarvekyulg, A. \& Seire, A. 1983. Changes of the bottom fauna in the Bay of Tallinn in the period of 1963-1977. In Hydrobiological Regime of the Baltic Sea, pp. 102-115. IZB, Acad. Sci. Estonian SSR, Tallinn (in Russian). 


\title{
Põhjaloomastiku kooslused Eesti rannikumere produktiivsetes piirkondades
}

\author{
Ilmar Kotta, Helen Orav-Kotta ja Jonne Kotta
}

Eesti rannikumere kõige produktiivsemad piirkonnad jäävad rannikunõlvade, basseinidevaheliste frontide, jõgede suudmealade ning reoveekollektorite suudmete lähedusse. Nendes piirkondades oli põhjaloomastiku biomass tunduvalt suurem, võrreldes ümbritsevate aladega. Üldlämmastikusisaldus korreleerus positiivselt põhjaloomastiku biomassiga. Toiteelementide sisalduse vähenemisel kasvas põhjaloomastiku liikide hulk Pärnu lahes, mujal sellist seost ei täheldatud. Kui põhjalähedased hoovused olid nõrgad, mõjus reovesi põhjaloomastikule negatiivselt. Väga suure reostuskoormuse korral akumuleerus setetesse väävelvesinik ning elustik hävis. 